\title{
Timothy Hay Business in Alberta: Business Models and Supply Chain Issues
}

\author{
Sajjad Zahir \\ Faculty of Management, University of Lethbridge, Lethbridge, Canada. \\ Email: zahir@uleth.ca \\ Received February $14^{\text {th }}, 2013$; revised March $14^{\text {th }}$, 2013; accepted April $8^{\text {th }}, 2013$ \\ Copyright (c) 2013 Sajjad Zahir. This is an open access article distributed under the Creative Commons Attribution License, which \\ permits unrestricted use, distribution, and reproduction in any medium, provided the original work is properly cited.
}

\begin{abstract}
This paper presents the business model and supply chain issues of Timothy hay business in Southern Alberta. Production, processing, marketing and distribution aspects of the business are described. Research was conducted using case-based field studies involving Timothy farmers, hay plant operators and forage research scientists. It is recommended that further research in raising yield of hay production and a better management of freight and exchange rate fluctuations will be greatly beneficial to this sector of business.
\end{abstract}

Keywords: Supply Chain; Timothy Hay; Forage; Compressed; Processing

\section{Introduction}

Grasslands have played an important role in the development of human civilization since the beginning as they were essential for growing animals to meet human needs for meat, dairy, hide and wool. In modern days, a new type of farming system, grassland agriculture has evolved underscoring the importance of grasses and legumes for livestock and land management. It has been emphasized that "the value of forages and grassland resources to national and human well-being will be defined and redetermined by new technologies and changes in human needs" in future grassland agriculture [1, p. 22].

Forage cultivation is a major agricultural activity in the Canadian prairies as it not only meets the demand of local livestock industries, but also various types of hays such as Alfalfa and Timothy are exported overseas. Since the early eighties, Canada (mainly the Prairie Provinces) has built a reputation as a premier supplier of forages and is the third largest exporter (the US by far is the largest supplier, followed by Australia) of this commodity in the world market with approximately $10 \%$ market share [2]. In this paper, we specifically consider Timothy hay (also known as compressed hay in Canada), its supply chain, processing and marketing issues. Major markets for Timothy hay, used variously for cattle (meat and dairy) and horses, are the US, Japan, Korea, Chinese Taipei, China, the Middle East and few other countries and areas on a smaller spot market basis. Although the relative size of the export value is small, it is important to consider this product as it represents value creation from a basic product with tremendous growth potentials in the new global context and emerging social movement scenarios.

Processing plants (i.e., hay plants) must specifically process the hay bundles before shipping in order to maintain nutritional quality. Plants also have to develop suppliers (i.e., farmers) guaranteeing sufficient supplies with a flexible purchasing plan. However, farmers often face a dilemma of producing alternative crops depending on variable market conditions. Dry land yields average 1.7 to 2.5 tonnes of Timothy per acre whereas irrigated land yields an average of and about 4.0 tonnes per acre on irrigation. Agricultural research activities for increasing per acre productivity are not always funded uniformly for all types of hays. Shipping of hay also requires optimized use of resources due to increasing fuel costs and for the best utilization of cargo space. In addition, how can the hay processing plants manage a diverse mix of products so as to keep their business sustainable in the face of growing demands for Timothy? This research is intended to explore the related issues and provide recommendations for the compressed hay industry in southern Alberta.

\section{Timothy Hay: Usage and Demand}

Growing income and higher living standards in Asia and the Middle East have increased demand for animal pro- 
tein and dairy products. Thus, the demand for hay is also growing with Timothy hay being an excellent source of fibre. It is also used in the equine industry in the US, Pacific-Rim Asia and the Middle East as fibre and forages are essential foundations of a horse's feeding program [3]. The beef and dairy industries in Asian countries are growing rapidly. However, with limited land bases they need to import large quantities of forages including Timothy hay, an excellent source of fibre, to supplement local production. Fibre is essential for proper rumen function. Canadian Timothy hay exports nearly doubled from 1998 to 2005 averaging around 300,000 to 400,000 tonnes per year with a valuation exceeding $\$ 100$ million per year [4]. The four principal components of Timothy hay supply chain are 1) growers, 2) processors/plants, 3) logistics/transportation providers, and 4) customers. The Alberta Government website [5] on Timothy and compressed hay lists the following Timothy hay growers and processors marketing perspectives given in Table 1.

Overseas customers have product-quality and productform as described in Alberta Government website below in Tables $\mathbf{2}$ and $\mathbf{3}$ [5].

To fulfill export/import regulatory requirements, items must get Phytosanitary Certification as overseas governments, especially the Japanese Ministry of Agriculture Forestry and Fisheries (MAFF), prohibits the importation of soil or plant species that could potentially be infested with Hessian fly larva or eggs. The Hessian fly has a tendency to infest wheat, barley, rye and other wheatgrass species, including quackgrass plant species and is

Table 1. Key issues for Timothy growers and processors.

\begin{tabular}{|c|c|}
\hline \multicolumn{2}{|c|}{ Marketing Perspectives of Timothy Growers and Processors } \\
\hline $\begin{array}{l}\text { Some of the Key } \\
\text { Issues for the Growers }\end{array}$ & $\begin{array}{l}\text { Some of the Issues } \\
\text { for Processors }\end{array}$ \\
\hline 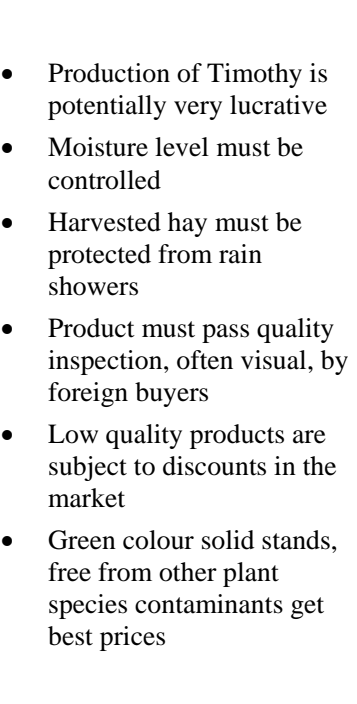 & $\begin{array}{l}\text { Processors exporting } \\
\text { compressed hay must have } \\
\text { facilities for supplying } \\
\text { products during the whole } \\
\text { year } \\
\text { - In addition to processing } \\
\text { facilities, they must have } \\
\text { dry and clean storage } \\
\text { facilities } \\
\text { Additional costs such as } \\
\text { brokerage fees, container } \\
\text { ocean freight and } \\
\text { rail/container freight costs, } \\
\text { export insurance, rejection } \\
\text { insurance, and port charges } \\
\text { should be included } \\
\text { Typical ocean and rail } \\
\text { freight cost is } \$ 100 / \text { ton, } \\
\text { broker fee is } \$ 8 / \text { ton, and } \\
\text { insurance cost is } \$ 7 / \text { ton for } \\
\text { Canadian exporters }\end{array}$ \\
\hline
\end{tabular}

Table 2. Factors that determines quality of Timothy hay products.

\section{Key Factors Determining Product quality}

- Leafy stems

- Good green colour

- Minimum brown leaves

- Long coarse stems with long heads

- Free of mold, weeds, soil, quackgrass and barley plant species, and other contaminants

- Moisture must be below $12 \%$

- There is no protein or fibre standards

- Quality is evaluated subjectively using visual appearance, colour and smell

Table 3. Typical product forms of compressed Timothy.

Key Product Form Features

- Forage is compressed to reduce shipping costs

- Typical compressed bale form is $14 " \times 18 " \times 18$ "

- $\quad$ Smaller square bales are preferred

- Bales are mechanically packed into 40-ft containers

- Large bales mixed with other feedstuffs are being explored as Total Mixed Rations

found throughout Western Canada. In order to kill any Hessian fly larva and eggs present in Timothy straw, a protocol using compression is presently under development [5].

As described above, the demand for Timothy hay is driven mostly by export in Canada where beef and dairy cattle consume forage products such as alfalfa in substantial quantities, but fibre needs in the diet are met by alternative sources. However, since the early 1990s there has been a social movement for grass-fed meat and dairy products in the United States. It has been recently investigated how such a grassroots movement had effected cultural change through market creation for grass-fed meat and dairy products [6]. Grass-fed products made up about 0.2 percent of the US meat and dairy sector [7] a few years ago. Although this was a small segment of the related market, the potential for growth cannot be ignored, especially in the context of emerging environmental awareness and a growing affinity for organic foods. Thus, Timothy hay may find higher demands in local beef and dairy industries, as well. The significance of this research has to be understood in light of such possibilities.

Some researchers [8] presented a synthesis of global climate change research on pasture and rangeland production. They observed that while rising $\mathrm{CO}_{2}$ is expected to stimulate forage production, drier regions will suffer from reduced production and other factors such as higher 
temperature, water shortage, and forage quality need be considered for predicting actual production of livestock. These phenomena add extra importance to cultivation of forages including Timothy hay in Canada, and management of its supply chain.

\section{A Brief Review of Studies on Relevant Agricultural Supply Chains}

Research works on the supply chain issues in the forage industry are rare. However, in the food grain sector, researchers have studied specific characteristics of the agrifood supply chains. For example, in one research work [9], a case study of the US grains industry has been performed leading to a conceptual framework for vertical co-ordination of supply chains. A closer vertical co-ordination has been a prevalent feature in the agri-food sectors of many countries [9]. There were some recent investigations of the wine supply chain for small and medium-sized producers of Australia and New Zealand. A case study of four South Australian wine producers has been reported to explore the complex relationships that existed within the supply chain of the organizations and their perceived key stakeholders [10]. Another group of researchers [11] investigated the nature of dissemination of information amongst supply chain partners (i.e., wineries and independent grape growers) in the New Zealand wine industry. Their findings highlighted the relationship between information sharing and successful supply chains.

Recently, agricultural biomass supply logistics have been subjects of academic research in the context of biofuel production. Such studies [12] used mathematical models and simulation techniques to describe the framework development of a dynamic integrated biomass supply analysis and logistics model (IBSAL). IBSAL helped optimizing collection, storage, and transportation of bulk corn to a bio-refinery. Their objective was to reduce costs, energy flow, and emissions of biomass operations. Later, the same IBSAL model developed at Oakridge National Laboratory, was used by [13] to evaluate cost, energy input and carbon emissions for a number of switchgrass supply options to a bio-refinery [14]. In addition, mathematical models have been proposed to design the supply chain, and manage the logistics of a biorefinery determining the number, size and location of biorefineries needed to produce biofuel using the available biomass [15]. Researchers [16] also investigated containerized handling of herbaceous biomass to minimize hauling cost. Herbaceous biomass such as switchgrass has been studied $[17,18]$ for co-firing with coal in large electric-generating plants in several regions of the US. Herbaceous biomass is also a potential feedstock for liquid fuel and commodity chemicals [19].
Such logistical evaluations have not been pursued in forage shipment in general and Timothy hay in particular mainly due to relative low volume of products in the supply chain. Therefore, plants and processors uniformly used standard containers for handling Timothy hay shipments.

\section{Research Methodology}

In this research, the goal is to identify existing supply chain issues of the Timothy hay business and recommend steps to further the value creation processes. The focus is at the supply end of the chain where we note three types of stakeholders: the farmers, the processors and forage researcher who all function within existing agricultural and regulatory policies of the government. The domain of investigation is central and southern area of the province of Alberta, Canada as it is the largest producer/exporter of Timothy hay in Canada. The methodology is based on data and information collection from field study and face-to-face and phone-based interviews. We located five Timothy hay plants (henceforth noted as P1, P2, P3, P4 and P5) within a range of $300 \mathrm{~km}$ in southern and central Alberta. One of the processors is owned by the Canadian Native Community, and they have identified issues unique to them. We visited these five plants, observed their operations and interviewed their operations managers. In addition, we also interviewed the owner of a sixth Timothy hay business (denoted by S1) that neither owns any plant nor grows any Timothy itself. It purchases hay from contract farmers and processes it in other plants before exporting it overseas. We discuss this special type of operation in more detail when we present models of Timothy businesses later in the paper. We also contacted two Timothy hay growers (henceforth noted as F1 and F2) and collected information about the farmers' perspectives. In addition, we interviewed a noted forage researcher (R1) from a federal agriculture research centre. We formulate findings as strategic issues and group those under four categories: Strength, Weakness, Opportunity and Threat (SWOT). Within each category, interviews were focused on four items: suppler, processing, transportation/logistics and customers-the four components in the supply chain.

\section{Knowledge Discovery}

The main objective of this research was to acquire knowledge about the current Timothy hay business in southern and central Alberta. This included identifying the stakeholder groups, making a record of supply chain issues listed by each group, understanding processing and challenges involved, and finally recommending initiatives for improvements in supply chain. 


\subsection{Processing Timothy Hay and Structure of Supply Chain}

While the processors do the final baling and compressing, growers themselves cut and bale the hay at their premises without compression and store them in a dry environment before deliveries are made to processors. Thus, they have some basic equipment such as baling machines, loaders and transportation vehicles. The processors/plants deal with the farmers through their buying agents who monitor the quality and moisture levels of Timothy hay ready for sale at the farmer's properties. Some processors own or lease land in order to manage the volume, quality and timing of crop production on their own. The remaining processing and other supply chain management issues are handled at the plants as described in Figure 1. Some processors have more than one size final compressed bales to meet a variety of customer demands. Usually, they have multiple compressors with different pressures ranging from $1700 \mathrm{lb}$ to $5200 \mathrm{lb}$ psi.

Controlling the moisture levels in hay is of paramount importance for quality control and buyers are ready to pay a premium price for high quality Timothy. Some plants have integrated a high volume dryer in the processing sequence for this purpose. It has been found that the most cost-effective plant has installed a power generation facility in its premises utilising readily available natural gas in Alberta. The exhaust heat from the power plant is used to feed in hot air for the dryer. Pest control is also very important. Otherwise, an entire shipment may be returned to sellers at their expenses. Once loosely baled hay is delivered to the input entry stage of the plant, it is unpacked for manual inspection and reading moisture levels. Then, it passes through a dryer (if available) on a conveyor belt to the compressor. Different plants have different pressure levels in their compressors ranging from $1700 \mathrm{lb} / \mathrm{psi}$ to $5200 \mathrm{lb} / \mathrm{psi}$. The compressed bales of hay are cut into standard sizes and are wrapped in polyester sheets before they are loaded into containers which are carried by trucks or train to a nearby port for shipment to distant customers.

The last stage in Figure 1 links with external logistics and transportation modes for final delivery to customers and is mostly handled by external transportation companies. Various hay exporters have mentioned about cost differences in shipping through the US versus the Canadian ports. Compression is essential for making the shipment of hay, a bulk product, in containers to overseas markets so as to make it cost-effective. Compressors are the main equipment, and there are local manufacturers for such equipment. At least one processing plant has been found to have in-house engineering expertise and technology to manufacture compressors and dryers in their attached workshop at substantial savings. This company also provided maintenance services to other plants and generated additional income for them. This was an interesting diversification of the hay business operations.

\subsection{Business Model}

Based on the investigation of the Timothy hay business, we discovered three main types of business models determined by the ownership of land and machineries (Table 4) leading to various levels of control, risk and need for special capabilities. Models A and B are traditional ones and they are characterised by the amount of investment a company makes in the Timothy hay business. Some processes grow their own hay but also purchase from farmers for additional supplies. For example, a business owned by the Canadian native community has access to vast land resources and workers. However, they had to acquire know how for using machineries, technologies and management. Moisture control is very important for quality assurance and, therefore, for sale price for hay. Thus, using dryers is often found to be an added

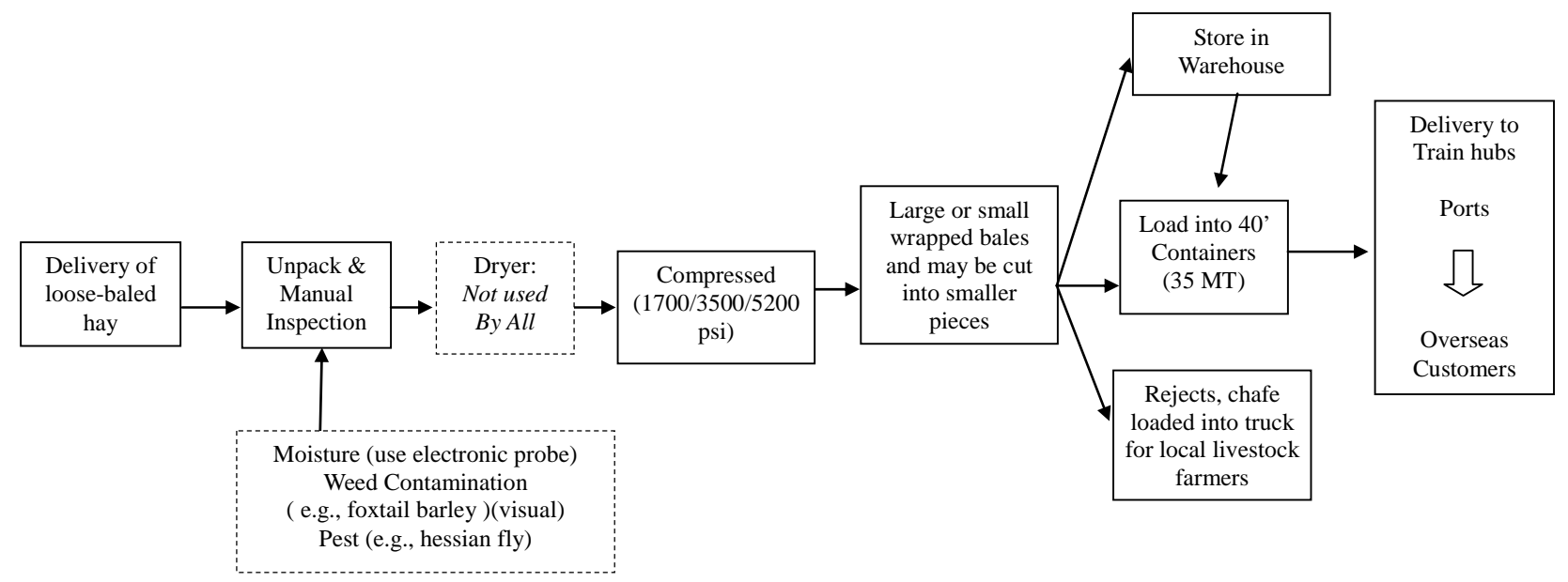

Figure 1. Flow diagram of processing inside a typical timothy hay plant. 
Table 4. Types of business models found active in Timothy hay business.

\begin{tabular}{ccccc}
\hline $\begin{array}{c}\text { Type of Business } \\
\text { Model }\end{array}$ & $\begin{array}{c}\text { Growing Own } \\
\text { Crop }\end{array}$ & Plant Ownership & Control, Cost, Liabilities & Specialties \\
\hline A & Yes & Yes & $\begin{array}{c}\text { Higher control, lower cost, higher } \\
\text { liabilities (e.g., weather related risks) }\end{array}$ & $\begin{array}{c}\text { Manage risk for higher } \\
\text { profitability }\end{array}$ \\
B & No & Yes & Lower control, market based cost, less liability & $\begin{array}{c}\text { Manage supply for profitability with } \\
\text { better technology } \\
\text { Premium price for premium } \\
\text { quality and special connection } \\
\text { with customers for market and } \\
\text { profit sustainability with skills for } \\
\text { managing cultural diversities }\end{array}$ \\
C & No & No & Less control, lower required investment, \\
higher cost
\end{tabular}

advantage. Some businesses have built their own dryers and others outsource the task to external operations. Model $\mathrm{C}$ has higher costs, but it is sustainable only if the quality is high enough to extract a premium price from buyers who are often available through special contacts and negotiations. To maintain such a relationship with special buyers, often in Asian and Middle-Eastern countries, businesses have to pay special attention to local values and ethics.

\subsection{Current Issues Perceived by Growers, Processors, and Researchers}

The SWOT analysis has been used as a simple framework for generating strategic alternatives from a situation analysis both at the corporate level and business unit level since it was first described in the late 1960's [18]. This form of analysis was used by the General Electric Growth Council in the 1980's. In this research we intend to address a complex strategic situation from standpoints of three different groups of stakeholders within a limited amount of available time. So, we have chosen this methodology as the theoretical foundation of the investigation as it concentrates on issues that potentially have the most impact. Based on this SWOT analysis, we present in Table 2 findings by aggregating the key issues that are applicable to each stakeholder group.

In addition, the stake holders were asked about their use of new technologies. Farmers are mostly tied to one or more local plants and thus do not have to go far for their businesses. Sometimes, they use online sources for information about weather, market conditions and suppliers of equipment and various inputs that go into the Timothy hay cultivation processes. Being a subsidiary of an US-based conglomerate, one of the plants reported that its Information Technology (IT) requirements were met by their centralized IT facilities located at the corporate IT centre in the US. Another plant official mentioned about using the Internet, e-mail systems, telephone and faxing tools for communications. None of them used advanced e-commerce technologies such as online pur- chases or payments yet. However, they expressed interests to adopt such technologies in the near future. The plants use machineries (i.e., presses and handling equipment) that are made, often customized, in both the US and Canada.

The processing plants, farmers and researchers have identified various issues that are listed in Table 5. It is clear that Timothy hay businesses have tremendous potentials for growth and profitability as the demand from overseas emerging economies is growing. Productivity can be increased by further research; more energy efficient equipment can be integrated into processing plants; and quality of hay can be maintained by moisture and pest control. A planned immigration policy can facilitate the availability of sustainable workforce at the plants, and a hedging scheme can offset losses from currency fluctuations.

\section{Summary and Discussion of Results}

Findings of this research are listed in Table 5 as contributed by the three groups of stakeholders who highlight the perspectives of supply chain issues in Timothy hay business in southern Alberta. One limitation of these findings is that they are based on a small group of participants. We anticipate a broader participation in further studies of this research. We can summarize the findings as follows:

1) Demand for Timothy hay is potentially unlimited hinting at a possibility for increasing export income and value creation in this primary product;

2) Supply from farmers can be increased in Canada as it is deemed very profitable compared to other crops;

3) Agricultural research in Timothy is lacking in Canada;

4) Farmers need more encouragement to expand Timothy hay cultivation and marketing;

5) Quality (e.g., moisture and pest control) has to be maintained for extracting higher price in the market;

6) Weather, exchange rate, freight costs, and attraction of competing crops remain sources of risks in the supply chain. 
Table 5. Issues reported by stakeholders; numbers in parentheses denote identities of members within a particular stakeholder group. MT: metric ton.

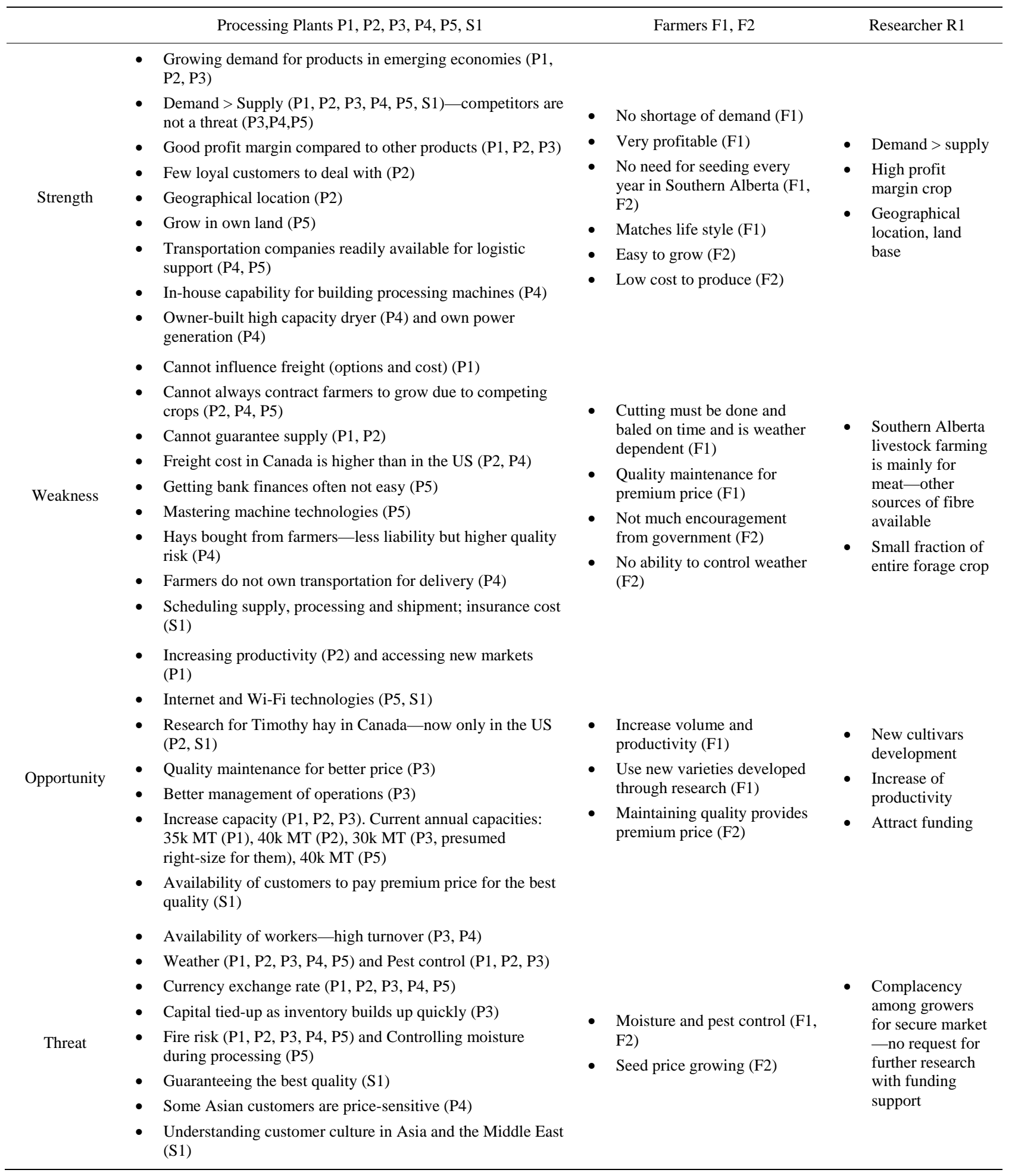

\section{Conclusion}

We observe that in southern Alberta, the supply chain of Timothy hay has evolved as an isolated sector from other crops as it is relatively small compared to the entire forage production system and mainly driven by export. However, if the sector undergoes expansion, it will be worthwhile to explore the Timothy supply chain issues in 
the context of an integrated forage development, new product development (i.e., pelletized form of Timothy hay, which can better preserve quality and be fed readily to animals) and management operation. It has been observed long ago [20] that economic benefits would be "considerably greater than those usually associated with range and pasture projects because multiple effects that accrue within the total operation are considered.” Further research following the investigations of References [21,22] for increasing Timothy yield will definitely help. Global warming, emerging economies, surplus land base and higher profitability - all together present an opportunity for capitalizing potentials of Timothy hay as a main crop through proper planning and management of its supply chain.

\section{REFERENCES}

[1] R. F. Barnes and C. J. Nelson, "Forages and Grasslands in a Changing World,” In: R. F. Barnes, C. J. Nelson, M. Collins and K. J. Moore, Eds., Forages: An Introduction to Grassland Agriculture, 6th Edition, Iowa State University Press of Blackwell Publishing, Ames, 2003.

[2] Manitoba Forage Council, 2011. http://www.mbforagecouncil.mb.ca

[3] J. D. Pagan, "Forages for Horses: More than Just Filler," In: J. D. Pagan, Ed., Advances in Equine Nutrition, Nottingham University Press, Nottingham, 1998, pp. 13-28.

[4] Sask Forage, 2011. http://feeds.innovation.usask.ca/pdfs/TheValueofSkForag e.pdf

[5] Alberta Agriculture and Rural Development, 2011. http://www1.agric.gov.ab.ca/\$department/deptdocs.nsf/all /sis11075

[6] K. Weber, K. L. Heinze and M. DeSoucey, "Forage for Thought: Mobilizing Codes in the Movement for GrassFed Meat and Dairy Products,” Administrative Sciences Quarterly, Vol. 53, No. 3, 2008, pp. 529-567. doi:10.2189/asqu.53.3.529

[7] US Department of Agriculture Economic Research Service, "Background Statistics,” 2006. http://www.ers.usda.gov/

[8] B. D. Campbell and D. M. Stafford Smith, “A Synthesis of Recent Global Change Research on Pasture and Range Production: Reduced Uncertainties and Their Management Implications," Agriculture Ecosystems \& Environment, Vol. 82, No. 1-3, 2000, pp. 39-55. doi:10.1016/S0167-8809(00)00215-2

[9] J. E. Hobbs and L. M. Young, "Closer Vertical Co-Ordination in Agri-Food Supply Chains: A Conceptual Framework and Some Preliminary Evidence," Supply Chain Management: An International Journal, Vol. 5, No. 3, 2000, pp. 131-143. doi:10.1108/13598540010338884

[10] A. Monday and T. Wood-Harper, "The Supply Chain of Small and Medium-Sized South Australian Wine Produc- ers,” Supply Chain Forum: An International Journal, Vol. No. 1, 2010, pp. 320-340.

[11] S. L. Forbes, D. A. Cohen and M. D. Clements, "The Dissemination of Information amongst Supply Chain Partners-A New Zealand Wine Industry Perspective," Supply Chain Forum: An International Journal, Vol. 11, No. 1, 2010, pp. 123-134.

[12] S. Sokhansanj, A. Kumar and A. Turhollow, "Development and Implementation of Integrated Biomass Supply Analysis and Logistics Model (IBSAL)," Biomass and Bioenergy, Vol. 30, No. 10, 2006, pp. 838-847. doi:10.1016/j.biombioe.2006.04.004

[13] A. Kumar and S. Sokhansanj, "Switchgrass (Panicum vigratum, L.) Delivery to a Biorefinery Using Integrated Biomass Supply Analysis and Logistics (IBSAL) Model," Bioresource Technology, Vol. 98, No. 5, 2007, pp. 10331044. doi:10.1016/j.biortech.2006.04.027

[14] S. Sokhansanj, A. Turhollow, J. Cushman and J. Cundiff, "Engineering Aspects of Collecting Corn Stover for Bioenergy,” Biomass and Bioenergy, Vol. 23, No. 5, 2002, pp. 347- 355. doi:10.1016/S0961-9534(02)00063-6

[15] S. D. Eksioglu, A. Acharya, L. E. Leightley and S. Arora, "Analyzing the Design and Management of Biomass-toBiorefinery Supply Chain,” Computers \& Industrial Engineering, Vol. 57, No. 4, 2009, pp. 1342-1352. doi:10.1016/j.cie.2009.07.003

[16] J. S. Cundiff and R. D. Grisso, "Containerized Handling to Minimize Hauling Cost of Herbaceous Biomass,” Biomass and Bioenergy, Vol. 32, No. 4, 2008, pp. 308-313. doi:10.1016/j.biombioe.2007.10.009

[17] P. V. Bush, D. M. Boylan, D. I. Bransby, H. A. Smith and C. R. Taylor, "Evaluation of Switchgrass as a Co-Firing Fuel in the Southeast,” Final Technical Report, DOE Cooperative Agreement No. DE-FC36-98G010349, 2001.

[18] Chariton Valley Resource Conservation and Development Inc., Alliant Energy, “Antares Group Inc. Chariton Valley Biomass Project-Switch Grass Co-Firing with Coal in Large-Scale Integrated Systems,” 2011. http://www.antaresgroupinc.com

[19] E. P. Learned, C. R. Christiansen, K. Andrews and W. D. Guth, "Business Policy, Text and Cases," Irwin.

[20] E. W. Anderson and M. L. Jernstedt, "Evaluating Economic Effects of Forage Development and Management," Journal of Range Management, Vol. 24, No. 3, 1971, pp. 174-180. doi:10.2307/3896767

[21] R. H. McKenzie, E. Bremer, P. G. Pfiffner, A. B. Middleton, T. Dow, M. Oba, A. Efetha and R. Hohm, "Yield and Quality Responses of Irrigated Timothy to Fertilizer Application in Southern Alberta," Canadian Journal of Plant Science, Vol. 89, No. 2, 2009, pp. 247-255.

[22] A. Efetha, T. Dow, R. H. McKenzie, D. R. Bennett and R. A. Hohm, "Effect of Irrigation Management on Yield, and Water Use Efficiency of Timothy Hay in Southern Alberta," Canadian Journal of Plant Science, Vol. 89, No. 6, 2009, pp. 1075-1088. doi:10.4141/CJPS09012 